\title{
Corporate Governance: International Context and Trends from 2005 to 2015
}

\author{
Miguel A. Jaimes-Valdez ${ }^{1}$, Carlos A. Jacobo-Hernandez ${ }^{1} \&$ Sergio Ochoa-Jimenez $^{1}$ \\ ${ }^{1}$ Department of Administrative Sciences, Sonora Institute of Technology, Cd. Obregon, Sonora, Mexico \\ Correspondence: Carlos A. Jacobo-Hernandez, Department of Administrative Sciences, Sonora Institute of \\ Technology, 5 de febrero 818-sur, Col. centro, Ciudad Obregon, Sonora, Mexico, C.P. 85000. Tel.: \\ 52-644-410-09-00 ext. 2706. E-mail: carlos.jacobo@itson.edu.mx
}

Received: January 6, 2017

Accepted: February 20, 2017 Online Published: February 22, 2017

doi:10.5539/ijbm.v12n3p158

URL: https://doi.org/10.5539/ijbm.v12n3p158

\begin{abstract}
Corporate governance is a topic that in recent years has been related to fraud and economic crises, which could be reasons for pessimism; however, this study views it as an opportunity to improve the organizational environment. Therefore, this exploratory study is conducted with the purpose of identifying the context in which corporate governance occurs and potential international trends. The review of the literature indicates that corporate governance codes based on the model of insider information are gradually being replaced by American and British models, which are characterized by democracy, transparency, and accountability. Similarly, there is emphasis on the importance of bringing organizations and interest groups closer together and building consensus to develop activities that are in the common interest and that provide benefits to all. Finally, further studies are recommended to improve national and international standards concerning corporate governance with the aim of balancing the interests of organizations and their stakeholders.
\end{abstract}

Keywords: corporate governance, international context, international trends, literature review

\section{Introduction}

The topic of corporate governance has been surrounded by controversy due to the recent unfortunate events of unethical and irresponsible behaviour by the managers of international corporations. The United States has seen the cases of Enron, WorldCom, and HealthSouth, whereas Europe has seen those of Parmalat, Royal Ahold, and Vivendi Universal (Soltani, 2014); similar cases have arisen in Pacific Asia and South America (Lessambo, 2014). On the other hand, it has been pointed out that the study of governance has been mainly in the regulation and legal issues, accounting and audit (Young \& Thyil, 2008). It is therefore expected that the dialog on corporate governance focused on practical issues as corporate fraud, abuse of power and social irresponsibility (Letza, Sun, \& Kirkbride, 2004). Faced with this situation, this study explores the context of and international trends in corporate governance as an exercise in identifying the main topics related to its study and discovering potential lines for further investigation. In short, rather than concentrating on the problem noted above and the consequences that still permeate the current state of affairs, this study attempts to identify the relationship of corporate governance with corporate governance codes and regulation, sustainability, and Corporate Social Responsibility (CSR), among other far-reaching issues. The goal is to demonstrate that, in different contexts around the world, there may exist universal principles such as proactivity and transparency that can be considered synonymous with good practice and that may transcend the practices mandated by local law.

\section{Theoretical Framework}

Corporate governance is the manner in which financial directors ensure the return on their investments (Shleifer \& Vishny, 1997). It may be claimed that corporate governance is a costly investment made to protect investors and managers with benefits that vary among companies (Aggarwal, Erel, Stulz, \& Williamson, 2010, quoted by Zhong, 2015); nevertheless, in general terms, corporate governance represents all processes which guarantee the proper administration of the company's assets and resources (Nitkin, 2012) and generally considers the structure, power, and decision-making process regarding collective activities (Von Tunzelmann, 2003, cited by Reuver \& Bouwman, 2012). One definition of corporate governance is the following:

Corporate governance is the system by which business corporations are directed and controlled. The corporate governance 
structure specifies the distribution of rights and responsibilities among different participants in the corporation - the board, managers, employees, shareholders and other stakeholders. It also spells out the rules and procedures for making decisions on corporate affairs. In so doing, corporate governance also provides the structure through which the company objectives are set, and the means of attaining those objectives and monitoring performance. (Organisation for Economic Co-operation and Development [OECD], 2004)

In addition, corporate governance is considered a system by which companies are directed and controlled and, specifically, by which the relations among management, shareholders, and stakeholders are organized, protecting their rights and promoting transparency (Arslantas \& Findikli, 2013). It is also considered a system of leadership, protocols that govern management control, property rights, and decision-taking, as well as other practices (Tihanyi, Graffin, \& George, 2015). In short, it is a system of laws, rules, and factors that control operations within the company (Gillan \& Starks, 1998, quoted by Gillan, 2006).

Moreover, corporate governance has been cited as the context within which organizations are embedded, given that it has been described as an environment of trust, ethics, and morals, representing a synergistic effort of society, that is, of interest groups, including the government, the general public, suppliers, and the business sector (Aras \& Growther, 2008). More specifically, it represents a set of processes, customs, policies, laws, and institutions that affect the manner in which the corporation is directed, managed, or controlled and whose purpose is to directly or indirectly influence the conduct of the organization with respect to its stakeholders (Dignam \& Lowry, 2006 quoted by Mostovicz, Kakabadse, \& Kakabadse, 2011). In the same vein, it is described as a framework for coordinating the relations among shareholders, the board of directors, management, and other stakeholders (OECD, 2004, quoted by Guo, Smallman, \& Radford, 2013).

This review of the various definitions of corporate governance makes it possible to identify the relationship between organizations and their stakeholders and shows that its proper functioning requires a balancing act between the two, as described by L'Huillier (2014). For this reason, corporate governance has been classified as a financial regulation that is necessary when imperfect relations abound between market forces and institutional factors with respect to ethical responsibility (Choudhury \& Harahap, 2007). Additionally, corporate governance and social responsibility concepts have shared characteristics because the first one demands that executives make their companies more transparent and accountable and the second one demands that companies support society with their activities (Taysir \& Pazarcik, 2013). Therefore, it is necessary to know CSR concept:

\footnotetext{
A management concept whereby companies integrate social and environmental concerns in their business operations and interactions with their stakeholders. CSR is generally understood as being the way through which a company achieves a balance of economic, environmental and social imperatives ("Triple-Bottom-Line-Approach"), while at the same time addressing the expectations of shareholders and stakeholders. (United Nations Industrial Development Organization [UNIDO], 2017)
}

Another concept of CSR is "the continuing commitment by business to contribute to economic development while improving the quality of life of the workforce and their families as well as of the community and society at large" (World Business Council for Sustainable Development [WBCSD], 2017). Finally, CSR "refers to companies taking responsibility for their impact on society and is important for the sustainability, competitiveness and innovation. It brings benefits for risk management, cost savings, access to capital, customer relationships, and human resource management" (European Commission, 2017).

\section{Material and Methods}

The present article is designed as a theoretical review that, for analytical purposes, classifies works as either qualitative or quantitative. The four stages implemented in accordance with Creswell (2009) are as follows: first, the Emerald and Elsevier scientific databases were chosen due to their prestige; second, a search was conducted using the keywords "corporate governance" to download empirical articles published between 2005 and 2015 in these journals; third, an exhaustive analysis was conducted regarding the host country, background, topics treated, and results; and, fourth, a comparative discussion identified the similarities and differences in the documents, ultimately leading to conclusions.

\section{Results}

Initially, 120 scientific articles relating to the issue of corporate governance were downloaded; after each was reviewed, 42 articles were selected for their originality and findings; these were separated into qualitative and quantitative studies and sorted by country of origin in an effort to broaden the context in which the phenomenon or object of study is viewed. 
The qualitative studies were classified into five themes: "Crisis and scandals as a starting point," "Codes of corporate governance," "Alignment of corporate governance mechanisms," "Corporate governance as it relates to CSR," and "Transaction costs" (see Table 1).

Table 1. Qualitative studies.

\begin{tabular}{llll}
\hline Number & Theme & Country/ Region & Author and year \\
\hline 1 & Crisis and scandals & Canada & Diochon (2010) \\
& & Europe & Spitzeck and Hansen (2010) \\
& & Nigeria & Adegbite (2014) \\
& & Ghana & Agyemang and Castellini (2015) \\
& \multirow{2}{*}{ Codes of corporate governance } & Germany & Rosen (2007) \\
& & Greece & Spanos (2005) \\
& & Nigeria & Adegbite (2012) \\
3 & Alignment of corporate governance mechanisms & India & Bajpai and Mehta (2014) \\
& & China & Guo et al. (2013) \\
& & U.S. and Europe & Payne (2006) \\
4 & Corporate governance and its relation to CSR & Poland & Yeoh (2007) \\
& & United Kingdom & Aras and Crowther (2008) \\
5 & Transaction costs & Turkey & Taysir and Pazarcik (2013) \\
& & Brazil & Carrer, Souza-Filho, and \\
& & & Brandão-Vinholis (2014) \\
& & Canada & Choudhury and Harahap (2007)
\end{tabular}

Note: Authors' work, including sources.

\subsection{Crises and Scandals}

Diochon (2010) takes recent corruption scandals as his starting point and explores the relationship between the board of directors and the promotion of entrepreneurship in Canada. It is confirmed that companies with top performance in innovation and goal-attainment are correlated with processes that promote entrepreneurship. Spitzeck and Hansen (2010) note that global financial crises have adversely affected the 20th century with greater frequency. Additionally, they identify stakeholders as indispensable to businesses, which leads them to study the relationship between the two in Europe, where they find that stakeholders are given a voice in strategic, managerial, and operational issues. Nevertheless, commitments combine a limited power with an inability to align the perspectives of all parties. Adegbite (2014) also studies the relationship between corporate governance mechanisms and good practices in Nigeria, where he finds rampant corruption in the private sector, which is characterized by a lack of skill and diversity on boards of directors, corrupt activism by shareholders' associations, and corrupt relations between the board and management at the expense of minority shareholders and other stakeholders. Finally, Agyemang and Castellini (2015) describe corporate governance in the developing country of Ghana, where they find that power is highly concentrated in the hands of a few large shareholders who exercise control over the company; although this situation solves the problem of agency, it poses challenges for minority shareholders.

\subsection{Codes of Corporate Governance}

Rosen (2007) undertakes the task of outlining a national schemata of the wave of corporate governance reforms that were introduced in Germany following the German Code of Good Governance of 3 February 2002 and the Laws of Corporations and Commercial Law. Although the principles and values propounded broke with tradition, the results show that they were widely accepted by the national and international business communities. Similarly, Spanos (2005) studies corporate governance practices in Greece, which are regulated by principles based on those issued by the OECD and influenced by the speculative events of 1999. Another problem is reported by Adegbite (2012), who calls for corporate governance codes to be disseminated and enforced in Nigeria, an African country rife with corruption. Specifically, he argues that corporate governance goes beyond the top management and the board of partners. Finally, Bajpai and Mehta (2014) examine the internal workings of corporate governance in two state-run companies in India, discovering that neither had named an independent director in its annual report, contravening corporate governance standards, which specifically state that the chairman of the board and the CEO must be different people. Therefore, they are in violation of the guidelines of the country's Ministry of Corporate Affairs. 


\subsection{Alignment of Corporate Governance Mechanisms at the International Level}

Guo et al. (2013) study the corporate governance of state-owned companies in China, finding that mechanisms implemented in the West have no impact in this Asian country due to the strong relationship between the companies and the State. For his part, Payne (2016) emphasizes that although clear distinctions remain, there is a growing similarity between American and European corporate governance. Yeoh (2007) offers an example of this similarity in his study of the hybrid corporate governance that dominates Poland and other countries in Central and Eastern Europe, where elements of the German model, featuring the use of inside information, are joined with the transparency and accountability of the British model. Nevertheless, Poland has introduced its own code of corporate governance, which is more similar to the latter, highlighting in turn the wave of German reforms.

\subsection{Corporate Governance and its Relationship with CSR}

Aras and Crowther (2008) examine the relationship between corporate governance and the CSR of companies listed in the "Financial Times Stock Exchange" (FTSE 100), that is, the 100 most highly valued companies on the London Stock Exchange. Their findings indicate that the more information companies have at their disposal, the better they perform in both areas. Taysir and Pazarcik (2013) review 908 articles on strategic management in the 1998-2010 period and find only 25 mentions of CSR and/or business ethics, a scarcity that merits reflection. Both cases highlight the need for more information about the relationship between corporate governance and CSR, given that research on this topic represents an opportunity for progress in its implementation in the business world.

\subsection{Transaction Costs}

Carrer et al. (2014) study the topics of transaction costs, sustainability, quality, and food safety in the Brazilian livestock sector, discovering multiple ways in which corporate governance serves as a bulwark against the risk of highly complex transactions and aids in developing a strategy to cope with an institutional framework marked by unpredictable and highly diverse supply and distribution channels. Choudhury and Harahap (2007) cite the cases of Enron and World.com as examples of the failure of the traditional model of corporate governance, for which they propose substituting a model that draws on the Islamic epistemological theory of the unity of knowledge, using the systems approach. Basically, the model submits corporate governance to an institutional framework concerned with ethics and values through consensus among managers and stakeholders under conditions of transparency, which reduces transaction costs and creates conditions under which the best management decisions may be taken.

The quantitative studies were divided into seven themes: "Corporate governance and its relationship with Sustainability and CSR," "Ownership structure," "Capital structure," "Company value and market value," " Financial performance," "The Sarbanes-Oxley Act," and "Regulation of corporate governance" (see Table 2).

Table 2. Quantitative studies

\begin{tabular}{llll}
\hline Number & Theme & Country/ Region & Author and year \\
\hline 1 & Corporate governance and & U.S. & Ruangviset, Jiraporn, and Kim (2014) \\
& its relationship with & France & Ducassy and Montandrau (2015) \\
& Sustainability and CSR & Malaysia & Said, Zainuddin, and Haron (2009) \\
& Malaysia & Janggu, Darus, Mohamed Zain, and Sawani (2014) \\
& Czech Republic & Krechovska and Prochazcova (2014) \\
& Australia & Lin, Li, and Bu (2015) \\
& Romania & Mihaela, Feleaga, and Feleaga (2014) \\
& Greece & Bekiris (2013) \\
& Ownership structure & South Korea & Min and Smyth (2014) \\
& Lebanon & Fahed-Sreih (2008) \\
& U.S. & Valenti, Luce, and Mayfield (2011) \\
& Indonesia & Puspitaningrum and Atmini (2012) \\
& & Europe & Dimitropoulos (2014) \\
& Capital structure & United Arab Emirates & Hussainey and Aljigri (2012) \\
& & United Kingdom & Florackis (2008) \\
& United Kingdom & Sikka (2008) \\
& & Reuver and Bouwman (2012)
\end{tabular}




\begin{tabular}{llll}
\hline \multirow{2}{*}{ value } & Canada & Berthelot, Francoeur, and Labelle (2012) \\
& & Chile, Colombia, and Peru & Cueto (2013) \\
& China & Li et al. (2015) \\
& \multirow{2}{*}{ Financial performance } & Europe & Honore, Munari, and Pottelsberghe (2015) \\
& & Taiwan & Lai and Chen (2014) \\
& India & Mishra and Mohanty (2014) \\
& Sarbanes-Oxley Act & U.S. & Chang, Chen, Chou, and Huang (2015) \\
& & U.S. & Chang and Sun (2010) \\
& & U.S. & Leventis and Dimitropoulos (2012) \\
& & Canada & Bozec and Dia (2012) \\
& Regulation of corporate & 21 OECD countries & Belloc and Pagano (2009) \\
\hline
\end{tabular}

Note: Authors' work, including sources.

\subsection{Corporate Governance and Its Relationship with Sustainability and CSR}

According to Ruangviset et al. (2014), under pressure from shareholders to increase company value, two major issues arise: corporate governance and CSR. A study conducted in the United States during 2001-2002 found a positive correlation between CSR and financial performance. Similarly, Ducassy and Montandrau (2015) study the influence of shareholders on the social performance of companies in France, showing that majority shareholders limit transparency with regard to CSR, which may indicate a lack of interest in this subject. Based on these findings, it is clear that independence for members of the board of directors is the basis for good CSR. Moreover, Said et al. (2009) examine the relationship between corporate governance characteristics and CSR disclosure among Malaysian companies listed on the stock exchange. They find that the property of corporate governance and the auditing committee are positively and significantly correlated with CSR disclosure.

Differently, Janggu et al. (2014) examine 100 companies listed on the Malaysian Stock Exchange to determine the impact of good corporate governance on sustainability disclosure under agency theory. They conclude that the size, professionalism, and method of appointment of the board of directors have a greater influence on sustainability disclosure than do their independence and ownership. In addition, Krechovska and Prochazcova (2014) highlight the need for corporate governance to change with respect to sustainability, which is the ability of businesses to positively influence environmental, economic, and social development. They find that awareness of the issue indeed exists in the business world of the Czech Republic but that it is not incorporated into practices, particularly among small and medium-sized enterprises, in which financial results are of paramount concern. Accordingly, sustainability does not even appear in performance measurement at the strategic level, though it should be an integral part of strategic planning.

Lin et al. (2015) study the relationship between corporate governance and community participation in Australian mining companies between 2005 and 2013. They confirm that corporate governance mechanisms improve citizen participation due to the companies' significant environmental, economic, and social impact. The obligation to invest in social programmes is not merely a legal requirement; rather, it is a question of corporate ethics. Finally, Mihaela et al. (2014) draw an analogy between corporate governance and a symphony orchestra, describing board members as musicians seeking to strike a particular tone. In general, appeals are made for corporate governance to be more proactive and lively, serving as the base of Maslow's pyramid, with education, a lifestyle and a strategy based on tangible and intangible benefits in the short and long terms.

\subsection{Ownership Structure}

Bekiris (2013) seeks to determine whether corporate governance mechanisms, the ownership structure, and the board are related in Greek companies. He finds that the variables are independent of one another. In addition, Fahed-Sreih (2008) studies the four structural elements of governance in 116 Lebanese companies: family, leadership, business, and property. In this regard, he finds that the first three elements influence the company's performance and survival whereas property does not. Moreover, Min and Smyth (2014) find a positive correlation among ownership liberalization, productivity, and better corporate governance in South Korea. The effect of foreign ownership and exports on productivity is greater in companies with better corporate governance. In another line of investigation, Puspitaningrum and Atmini (2012) seek to test whether three mechanisms of corporate governance - the ownership structure, individual commissioners, and the characteristics of the audit committee - affect the level of online financial disclosure in 420 countries in Indonesia. They find that only the third factor affects the outcome, particularly the number of times that the audit committee meets. Finally, Valenti et al. (2011) discover that a decrease in the total number of directors and the number of external directors is 
significantly related to companies' poor performance in the United States.

\subsection{Capital Structure}

Dimitropoulos (2014) studies how the quality of corporate governance affects the capital structure and level of debt for European football clubs. He finds that mechanisms of corporate governance such as larger boards of directors, independence, and dispersed ownership (managerial and institutional) reduce the level of debt, leverage, and, consequently, financial instability. In another study, Hussainey and Aljigri (2012) examine the degree to which both internal and external corporate governance mechanisms affect the capital structure of companies in the United Arab Emirates. The consequences of financial policies applied in these companies confirm the above findings; managers should thus be aware of the benefits of adopting international standards because the implementation of corporate governance codes improves their efficiency and effectiveness, which has a positive impact on the stock markets. Florackis (2008) seeks to expand the empirical literature on the determinants of agency costs by using a broad sample of listed companies in the United Kingdom. Capital structure, bank debt, and debt maturity are important tools of corporate governance. Simultaneously, ownership by directors, managerial compensation, and ownership concentration are closely associated with agency costs. Finally, Sikka (2008) seeks to stimulate debate on the creation of corporate governance mechanisms and processes that would help ensure an equitable distribution of income and wealth for workers in the United Kingdom. Presently, however, mechanisms, structures, and institutional processes that can achieve this goal are lacking.

\subsection{Company Value and Market Value}

Reuver and Bouwman (2012) study corporate governance mechanisms for innovations in mobile service value networks because the literature notes the power, confidence, and contracts that dominate businesses. The first is used in the early stages of developing services and technology; the second during implementation and selling; and the third in marketing. In the same year, while seeking to test the relationship between corporate governance mechanisms and company value in Canada, Berthelot et al. (2012) are surprised to discover that most of the mechanisms had no significant effect, though they considered only the industrial context. Nevertheless, this finding shows a lack of investor interest in corporate governance. Subsequently, Cueto (2013) studies the relationship among highly concentrated ownership structures, corporate governance mechanisms, and company values in the South American countries of Chile, Colombia, and Peru, discovering that to minimize the concentration of ownership, companies resort to mechanisms that include leveraging, having the CEO double as the chairman of the board and offering shares in two or more exchanges, which is known as cross-listing. Finally, in their study of the relationship between corporate governance and the market value of state-owned enterprises of China, Li et al. (2015) determine that the State's ownership role has no negative effect on their performance whereas corruption by managers does.

\subsection{Financial Performance}

Honore et al. (2015) examine whether corporate governance practices of aligning the interests of shareholders and managers affect the resources of 177 European research and development firms. Such enterprises are essential for the creation of new products and processes to increase productivity and sustainability. They find that practices have been designed to respond to the short-term expectations of financial markets, which could prove harmful in the long term. In their analysis of the relationship between organizational management and stakeholders, Lai and Chen (2014) find a positive correlation between the quality of corporate governance and partners' earnings. Good governance serves stakeholders' interests with regard to growth potential and business relationships, among others. Finally, in their study of 141 Indian companies listed on the stock exchange, Mishra and Mohanty (2014) find that because there is indeed a relationship between corporate governance and financial performance, best practices should be adopted in this regard.

\subsection{The Sarbanes-Oxley Act}

According to Chang et al. (2015), the Sarbanes-Oxley Act mandates a variety of corporate governance mechanisms to improve transparency in the quality of financial information. Their study aims to determine the relationship between this rule on the structures of corporate governance in the United States and the market perception of income information and business profits. The results show that in a highly competitive industry, organizations with weak structures have greater incentives to maximize shareholders' wealth. When they are over-leveraged, companies with weak structures are also slower to adjust than companies with strong structures.

On the same topic, Chang and Sun (2010) begin by stating the Sarbanes-Oxley Act indeed helps corporate governance mechanisms improve the transparency of financial information in the United States. They find that 
this regulation, particularly the measures requiring companies to reconfigure and implement their corporate governance structures, results in the disclosure of the independent audit committee's report and other mechanisms that increase the credibility of accounting profits. Finally, Leventis and Dimitropoulos (2012) examine the role of corporate governance in revenue management by American banks during the era of the Sarbanes-Oxley Act (2003-2008), finding that good corporate governance behaviour reduces aggressive revenue management and that banks with efficient corporate governance thus record lower revenues.

\subsection{Regulation of Corporate Governance}

Belloc and Pagano (2009) provide an overview of the evolution of corporate governance and politics in the United States and Europe. The strategy stems from different roots in the two regions: in the former, so-called "American populism" seeks to bring capitalist dynasties under control, whereas in "social-democratic Europe," workers and capitalists consider the costs and benefits of collective actions. Accordingly, the introduction of American laws in Europe is inevitable, and the American model could thus disarm both trade unions and family dynasties, which would generate socioeconomic instability and diminish investment in human capital by many stakeholders. Subsequently, Bozec and Dia (2012) study corporate governance practices in Canada in the post-Enron era, showing that regulation has improved them. The legislation addresses the composition, attributes, and work of the boards of directors and committees. However, it should be noted that corporate governance practices that have yet to be regulated do not show improvements.

\section{Discussion}

The qualitative studies are balanced in terms of the frequency with which they cover different topics, with four articles covering crises, scandals, and codes of corporate governance, three studies covering the international approval of mechanisms, and two articles covering the relationship of corporate governance with transaction costs and CSR.

Predictions of more frequent global economic crises in the coming century lead to reflection on drawing stakeholders closer together because these determine the success or failure of companies (Spitzeck \& Hansen, 2010). In particular, this action contributes to goal attainment and improved innovation (Diochon, 2010). Otherwise, homogeneity and the lack of skill by the board of directors foster corruption (Adegbite, 2014).

European and American codes of corporate governance have begun the process of integrating with each other (Payne, 2006). Given the influence of both the German model of privileged information and the British model of transparency and accountability, the balance is tilting ever more towards the latter in central and eastern Europe. Even Germany has initiated a process of transformation in this direction (Yeoh, 2007). Nevertheless, there are exceptions, such as China, where the mechanisms implemented in the West have no impact on the state-run companies of this Asian country (Guo et al., 2013). Another problem that has been identified is the excessive concentration of power in the hands of majority shareholders, to the detriment of minority shareholders (Agyemang \& Castellini, 2015).

As noted in the previous paragraph, Germany has begun regulating good corporate governance through codes that depart from that country's tradition (Rosen, 2007). The crisis that Greece faced in the late 20th century has led to regulation based on the OECD principles (Spanos, 2005). In some cases, such as Nigeria, combatting corruption does not require the creation of new codes but rather the implementation of existing codes (Adegbite, 2012). A similar case is found in India, where two state-run companies have not appointed an independent director, violating the country's rules (Bajpai \& Mehta, 2014). It would seem that crises and unwanted circumstances such as corruption drive new regulations and codes of corporate governance, though the need to adapt these measures to the specific particular contexts of countries should be stressed; doing so would ensure a better future for management practices.

In almost 1000 articles on strategic management published between 1998 and 2010, only 25 address the topic of CSR or corporate ethics (Taysir \& Pazarcik, 2013). Such studies are essential for knowledge generation and dissemination, which could yield better results in both corporate governance and CSR (Aras \& Crowther, 2008).

Pluralistic forms of corporate governance are found to reduce the risks of transaction costs (Carrer et al., 2014). The cases of Enron and World.com show that the traditional model of corporate governance is ineffective; a new model is proposed based on a transparent institutional framework that is rooted in ethics and values and guided by consensus among managers and stakeholders, which would make possible a reduction in transaction costs (Choudhury \& Harahap, 2007).

The quantitative studies thoroughly cover the relation of sustainability and CSR with corporate governance, with seven scientific articles; five studies focus on ownership and the capital structure; and overall value and market 
value are treated in four articles. Financial performance and the Sarbanes-Oxley Act are the subject of three articles, and finally, two articles address the regulation of corporate governance.

A positive correlation between CSR and financial performance has been identified in the United States (Ruangviset et al., 2014). Although France does not seem to be a priority, it is found that the independence of members of the board of directors is essential for appropriate CSR (Ducassy \& Montandrau, 2015). Similarly, in Malaysia, CSR disclosure is positively correlated with the ownership of corporate governance and the audit committee (Said et al., 2009). In the same country, the size, professionalism, and appointment of the board of directors affect the disclosure of sustainability (Janggu et al., 2014). In the Czech Republic, it is clear that there is awareness of the issue of sustainability in the business world; however, it has not been incorporated into business practice, particularly among small and medium-sized enterprises (Krechovska \& Prochazcova, 2014).

A study in Australia confirms that corporate governance mechanisms can improve citizen participation (Lin et al., 2015). This finding is consistent with the proposal of a model of proactive corporate governance that seeks short-term and long-term benefits (Mihaela et al., 2014).

It has been shown that in Greece, the ownership structure is a mechanism that is independent of the board (Bekiris, 2013). In this regard, in Lebanon, leadership and business, rather than ownership, are directly related to the survival of the company (Fahed-Sreih, 2008). In South Korea, a positive correlation exists between the release of property and better corporate governance (Min \& Smyth, 2014). In the same vein, in Indonesia, the ownership structure and commissioners have no effect on online financial disclosure; the characteristics of the audit committee are the only factor that increases online financial disclosure (Puspitaningrum \& Atmini, 2012). Finally, a reduction in the number of directors is related to poor performance in the United States (Valenti et al., 2011).

The capital structure is important in the case of European football clubs, in which corporate governance mechanisms such as the size, independence, and ownership of the board of directors reduce the clubs' financial instability (Dimitropoulos, 2014). In the United Arab Emirates, the relationship between corporate governance and the capital structure has been confirmed. Therefore, the codes should be implemented to increase efficiency (Hussainey \& Aligri, 2012). In line with this proposal, the mechanisms of the capital structure, bank debt, and debt maturity are important determinants of the agency cost in the United Kingdom (Florackis, 2008). In this country, mechanisms for the distribution of wealth to employees should be developed where none currently exist (Sikka, 2008).

Company value is fundamental for shareholders, though a study in Canada shows no relationship between some mechanisms of corporate governance and the company's market value, which could indicate a lack of interest in this subject among investors (Berthelot et al., 2012). In Chile, Colombia, and Peru, it is shown that organizations resort to mechanisms such as leverage and offering shares on two or more exchanges to minimize the ownership concentration (Cueto, 2013). Similarly, corporate governance mechanisms such as power, confidence, and contracts are used in the development, implementation, and marketing stages, respectively, by companies in mobile service integrated value networks (Reuver \& Bouwman, 2012).

Regarding financial performance, corporate governance practices are designed to align the interests of shareholders and managers of European firms in the field of innovation and development to meet short-term needs (Honore et al., 2015). In Taiwan, a positive correlation between the quality of corporate governance and partners' earnings indicates that this type of governance serves the interests of all stakeholders (Lai \& Chen, 2014). The same result is found in India, where companies listed on the Exchange have corporate governance mechanisms that are directly related to financial performance. They should thus abide by best practices in this regard (Mishra \& Mohanty, 2014).

The Sarbanes-Oxley Act is a mandate to improve corporate governance mechanisms with regard to the transparency of financial information (Chang et al., 2015). It has been found that this regulation helps companies increase the credibility of their accounting profits in the United States (Chang \& Sun, 2010). Good governance also reduces aggressive revenue management by banks in this country (Leventis \& Dimitropoulos, 2012).

It appears that laws on good governance will inevitably be introduced in Europe. This could potentially mean dismantling workers' unions and family dynasties, which would result in socioeconomic instability (Belloc \& Pagano, 2009). In Canada, practices that have been regulated in the post-Enron era have improved, in contrast to those that have not been regulated (Bozec \& Dia, 2012).

The qualitative and quantitative studies cover various topics, with the former discussing crises and scandals, codes of corporate governance, the alignment of mechanisms of corporate governance, CSR, and transaction 
costs. The quantitative studies discuss sustainability and CSR, ownership and the capital structure, company value and market value, financial performance, the Sarbanes-Oxley Act, and the regulation of corporate governance.

This finding indicates that qualitative studies address issues related to honour, solidarity, justice, the regulation of good practices, and the gradual unification of corporate governance mechanisms. Meanwhile, quantitative studies reflect economic and financial issues, the regulation of corporate governance, and social, environmental, and economic responsibility.

\section{Conclusions}

Corporate governance is an issue that in recent years has been constantly linked to economic crisis, corruption, and abuse of power, all due to the recent scandals that have dominated headlines in the media; however, this study indicates a source of opportunities to improve economic performance and company value, particularly if best practices are considered. Although it is difficult to define good corporate governance, each country, in accordance with its specific characteristics, must determine and create the most appropriate laws, regulations, etc., to be consistent with the welfare of business, society, and government. However, there are certain principles that appear to be universal: for example, drawing together stakeholders and achieving consensus by dialogue through various means of participation; transparency and accountability so that society has a chance to get to know companies' most important activities and their impact in the short, medium, and long terms to be prepared to take preventive and corrective actions; and, finally, respect for human dignity because social welfare should transcend a business's economic benefit as a paramount concern in all areas. This seems to be the American and British model of corporate governance, which is constantly growing in Europe and could undoubtedly be reflected next in other regions such as Asia and Latin America.

Although the present review of the literature provides a broad overview of various events related to the context and trends of corporate governance around the world, further studies of both a qualitative and quantitative nature are needed to analyse in detail each of the elements described here and to broaden the scope of this information. Similarly, as codes of corporate governance based on privileged information converge with those based on transparency and accountability, further studies may provide updates on such norms at the national and international levels and contribute to their efficiency, coherence, transferability, and expedited communication. This is for the purpose of balancing the benefits of organizations and their stakeholders, for which present and future generations will certainly be grateful.

\section{References}

Adegbite, E. (2012). Corporate governance regulation in Nigeria. Corporate Governance: The international journal of business in society. https://doi.org/10.1108/14720701211214124

Adegbite, E. (2014). Good corporate governance in Nigeria: Antecedents, propositions and peculiarities. International Business Review. https://doi.org/10.1016/j.ibusrev.2014.08.004

Agyemang, O. S., \& Castellini, M. (2015). Corporate governance in an emergent economy: a case of Ghana. Corporate Governance. https://doi.org/10.1108/CG-04-2013-0051

Aras, G., \& Crowther, D. (2008). Governance and sustainability. Management Decision. https://doi.org/10.1108/00251740810863870

Arslantas, C., \& Findikli, M. (2013). Relations with stakeholders in Turkey: the sample of ISE-50 Index. Corporate Governance: The international journal of business in society. https://doi.org/10.1108/CG-12-2010-0095

Bajpai, A., \& Mehta, M. (2014). Empirical Study of Board and Corporate Governance Practices in Indian Corporate Sector: Analysis of CG Practices of ITC and ONGC. Procedia Economics and Finance. https://doi.org/10.1016/S2212-5671(14)00174-9

Bekiris, F. V. (2013). Ownership structure and board structure: are corporate governance mechanisms interrelated? Corporate Governance: The international journal of business in society. https://doi.org/10.1108/CG-02-2011-0013

Belloc, M., \& Pagano, U. (2009). Co-evolution of politics and corporate governance. International Review of Law and Economics. https://doi.org/10.1016/j.irle.2008.11.002

Berthelot, S., Francoeur, C., \& Labelle, R. (2012). Corporate governance mechanisms, accounting results and stock valuation in Canada. International Journal of Managerial Finance. https://doi.org/10.1108/17439131211261251 
Bozec, R., \& Dia, M. (2012). Convergence of corporate governance practices in the post-Enron period: behavioral transformation or box-checking exercise? Corporate Governance: The international journal of business in society. https://doi.org/10.1108/14720701211214115

Carrer, M. J., Souza-Filho, H. M., \& Brandão-Vinholis, M. M. (2014). Plural forms of governance in the beef industry: A case study in Brazil. British Food Journal. https://doi.org/10.1108/BFJ-04-2012-0089

Chang, J., \& Sun, H. L. (2010). Does the disclosure of corporate governance structures affect firms' earnings quality? Review of Accounting and Finance. https://doi.org/ 10.1108/14757701011068048

Chang, Y. K., Chen, Y. L., Chou, R. K., \& Huang, T. H. (2015). Corporate governance, product market competition and dynamic capital structure. International Review of Economics and Finance. https://doi.org/10.1016/j.iref.2014.12.013

Choudhury, M. A., \& Harahap, S. S. (2007). Decreasing corporate governance in an ethico-economic general equilibrium model of unity of knowledge. Corporate Governance: The international journal of business in society. https://doi.org/10.1108/14720700710827185

Creswell, J. W. (2009). Research design: Qualitative, quantitative, and mixed methods approaches. London, United Kingdom: SAGE.

Cueto, D. C. (2013). Substitutability and complementarity of corporate governance mechanisms in Latin America. International Review of Economics and Finance. https://doi.org/10.1016/j.iref.2012.07.008

Dimitropoulos, P. (2014). Capital structure and corporate governance of soccer clubs. Management Research Review. https://doi.org/10.1108/MRR-09-2012-0207

Diochon, M. C. (2010). Governance, entrepreneurship and effectiveness: exploring the link. Social Enterprise Journal. https://doi.org/ 10.1108/17508611011069248

Ducassy, I., \& Montandrau, S. (2015). Corporate social performance, ownership structure, and corporate governance in France. Research in International Business and Finance. https://doi.org/10.1016/j.ribaf.2015.02.002

European Commission. (2017). Corporate Social Responsibility (CSR). Europe: European Commission. Retrieved from http://ec.europa.eu/growth/industry/corporate-social-responsibility_en

Fahed-Sreih, J. (2008). An exploratory study on a new corporate governance mechanism. Management Research News. https://doi.org/10.1108/01409170910922023

Florackis, C. (2008). Agency costs and corporate governance mechanisms: Evidence for UK firms. International Journal of Managerial Finance. https://doi.org/10.1108/17439130810837375

Gillan, S. L. (2006). Recent Developments in Corporate Governance: An Overview. Journal of Corporate Finance. https://doi.org/10.1016/j.jcorpfin.2005.11.002

Guo, L., Smallman, C., \& Radford, J. (2013). A critique of corporate governance in China. International Journal of Law and Management. https://doi.org/ 10.1108/IJLMA-10-2011-0012

Honoré, F., Munarib, F., \& Pottelsberghe, B. (2015). Corporate governance practices and companies' R\&D intensity: Evidence from European countries. Research Policy. https://doi.org/10.1016/j.respol.2014.10.016

Hussainey, K., \& Aljifri, K. (2012). Corporate governance mechanisms and capital structure in UAE. Journal of Applied Accounting Research. https://doi.org/10.1108/09675421211254849

Janggu, T., Darus, F., Mohamed Zain, M., \& Sawani, Y. (2014). Does good corporate governance lead to better sustainability reporting? an analysis using structural equation modelling. Procedia - Social and Behavioral Sciences. https://doi.org/10.1016/j.sbspro.2014.06.020

Krechovska, M. \& Prochazkova P. T. (2013). Sustainability and its Integration into Corporate Governance Focusing on Corporate Performance Management and Reporting. Procedia Engineering. https://doi.org/10.1016/j.proeng.2014.03.103

Lai, J. H., \& Chen, L. Y. (2014). The valuation effect of corporate governance on stakeholder wealth: Evidence from strategic alliances. International Review of Economics and Finance. https://doi.org/10.1016/j.iref.2014.01.010

Lessambo, F. I. (2014). The International Corporate Governance System: Audit Roles and Board Oversight. London, United Kingdom: Palgrave Macmillan. 
Letza, S., Sun, X., \& Kirkbride, J. (2004). Shareholding Versus Stakeholding: a critical review of corporate governance. Blackwell Publishing Ltd. https://doi.org/10.1111/j.1467-8683.2004.00367.x

Leventis, S., \& Dimitropoulos, P. (2012). The role of corporate governance in earnings management: experience from US banks. Journal of Applied Accounting Research. https://doi.org/10.1108/09675421211254858

L'Huillier, B. M. (2014). What does "corporate governance" actually mean? Corporate Governance. https://doi.org/10.1108/CG-10-2012-0073

Li, C., Zheng, W., Chang, P., \& Li, S. (2015). The correlation between corporate governance and market value: regime or signal? China Finance Review International. https://doi.org/10.1108/CFRI-06-2013-0067

Lin, P. T., Li, B., \& Bu, D. (2015). The relationship between corporate governance and community engagement: Evidence from the Australian mining companies. Resources Policy. https://doi.org/10.1016/j.resourpol.2014.11.004

Mihaelaa, D., Feleaga, N. \& Feleaga, L. (2014). Corporate Governance like a Symphony Orchestra. Procedia Economics and Finance. https://doi.org/10.1016/S2212-5671(14)00619-4

Min, B. S., \& Smyth, R. (2014). Corporate governance, globalization and firm productivity. Journal of World Business. https://doi.org/10.1016/j.jwb.2013.07.004

Mishra, S., \& Mohanty, P. (2014). Corporate governance as a value driver for firm performance: evidence from India. Corporate Governance. https://doi.org/ 10.1108/CG-12-2012-0089

Mostovicz, E. I., Kakabadse, N. K. \& Kakabadse, A. (2011). Corporate governance: quo vadis? Corporate Governance: The international journal of business in society. https://doi.org/ 10.1108/14720701111177019

Nitkin, M. (2012). Does governance culture exist and can it be mandated? Accounting \& Organizational Change. https://doi.org/10.1108/18325911211258326

OECD. (2004). Corporate governance. United States of America: OECD. Retrieved from https://usoecd.usmission.gov/corporate_governance.html

Payne, A. (2006). Corporate governance in the USA and Europe: they are closer than you might think. Corporate Governance: The international journal of business in society. https://doi.org/10.1108/14720700610649472

Puspitaningrum, D., \& Atmini, S. (2012). Corporate governance mechanism and the level of internet financial reporting: Evidence from Indonesian companies. Procedia Economics and Finance. https://doi.org/10.1016/S2212-5671(12)00075-5

Reuver, M., \& Bouwman, H. (2012). Governance mechanisms for mobile service innovation in value networks. Journal of Business Research. https://doi.org/10.1016/j.jbusres.2011.04.016

Rosen, R. v. (2007). Corporate governance in Germany. Journal of Financial Regulation and Compliance. https://doi.org/10.1108/13581980710726778

Ruangviset, J., Jiraporn, P., \& Kim, J.C. (2014). How does Corporate Governance influence Corporate Social Responsibility? Procedia - Social and Behavioral Sciences. https://doi.org/10.1016/j.sbspro.2014.07.554

Said, R., Zainuddin, Y. \& Haron, H. (2009). The relationship between corporate social responsibility disclosure and corporate governance characteristics in Malaysian public listed companies. Social Responsibility Journal. https://doi.org/10.1108/17471110910964496

Shleifer, A., \& Vishny, R. W. (1997). A survey of corporate governance. The journal of finance, 52(2), 737-783. Retrieved from http://scholar.harvard.edu/files/shleifer/files/surveycorpgov.pdf

Sikka, P. (2008). Corporate governance: what about the workers? Accounting, Auditing \& Accountability Journal. https://doi.org/10.1108/09513570810907438

Soltani, B. (2014). The Anatomy of Corporate Fraud: A Comparative Analysis of High Profile American and European Corporate Scandals. Journal of Business Ethics. https://doi.org/10.1007/s10551-013-1660-z

Spanos, L. J. (2005). Corporate governance in Greece: developments and policy implications. Corporate Governance: The international journal of business in society. https://doi.org/10.1108/14720700510583430

Spitzeck, H., \& Hansen, E. G. (2010). Stakeholder governance: how stakeholders influence corporate decision making. Corporate Governance: The international journal of business in society. https://doi.org/10.1108/14720701011069623

Taysir, E. A., \& Pazarcik, Y. (2013). Business ethics, social responsibility and corporate governance: Does the 
strategic management field really care about these concepts? Procedia - Social and Behavioral Sciences. https://doi.org/10.1016/j.sbspro.2013.10.497

Tejeda, H., \& Feuz, D. (2014). Determining the effectiveness of optimal time-varying hedge ratios for cattle feeders under multiproduct and single commodity settings. Agricultural Finance Review. https://doi.org/10.1108/AFR-11-2013-0038

Tihanyi, L., Graffin, S., \& George, G. (2015). Rethinking governance in management research. Academy of Management Journal. https://doi.org/10.5465/amj.2014.4006

Valenti, M. A., Luce, R., \& Mayfield, C. (2011). The effects of firm performance on corporate governance. Management Research Review. https://doi.org/10.1108/01409171111116295

WBCSD (2017). Corporate Social Responsibility (CSR). United States of America: WBCSD. Retrieved from http://old.wbcsd.org/work-program/business-role/previous-work/corporate-social-responsibility.aspx

Yeoh, P. (2007). Corporate governance models. Managerial Law. https://doi.org/10.1108/03090550710816483

Young, S., \& Thyil, V. (2008). A holistic model of corporate governance: a new research framework. Corporate Governance: The international journal of business in society. https://doi.org/10.1108/14720700810853437

Zhong, N. (2015). Corporate governance of Chinese privatized firms: Evidence from a survey of non-listed enterprises. Journal of Comparative Economics. https://doi.org/10.1016/j.jce.2015.05.003

\section{Copyrights}

Copyright for this article is retained by the author(s), with first publication rights granted to the journal.

This is an open-access article distributed under the terms and conditions of the Creative Commons Attribution license (http://creativecommons.org/licenses/by/4.0/). 